Daniel Floquet*

Universidade do Porto - ILCML/CETAPS

\title{
Da dor e do secreto prazer: notas sobre a representação da violência em Maria Velho da Costa
}

\section{Resumo:}

Este ensaio propõe uma leitura do romance Irene ou o contrato social (2000), de Maria Velho da Costa, à luz da temática da violência, atribuindo-lhe um papel estruturante no desenvolvimento do próprio enredo. Assim, procuro compreender as estratégias narrativas empregadas para representar as diferentes formas de violência exercidas por suas personagens. Convocando ocasionalmente outras de suas obras, busco também demonstrar como a autora nem sempre representa a violência por uma perspectiva negativa, conferindo-lhe muitas vezes um estatuto ambivalente.

Palavras-chave:

Maria Velho da Costa, Irene ou o contrato social, Violência, Mal, Intertextualidade

\section{Abstract:}

This essay offers a reading of Maria Velho da Costa's novel Irene ou o contrato social (2000) in the context of the theme of violence, giving it a central role in the development of the plot. Bearing this idea in mind, I try to look into the narrative strategies used to represent the different ways in which violence is handled by its characters. Resorting occasionally to other works by the author, I also try to show how Maria Velho da Costa does not always represent violence from a negative perspective, often giving it an ambivalent status.

\section{Keywords:}

Maria Velho da Costa, Irene ou o contrato social, Violence, Evil, Intertextuality

"Fomos maus espectadores da vida, se não vimos também a mão que delicadamente - mata" Friedrich Nietzsche, Além do Bem e do Mal.

Maria Velho da Costa, em sua coletânea de contos Dores, publicada em 1994, possui uma narrativa intitulada "Iniciais", em que as personagens são chamadas exclusivamente pelas iniciais de seus nomes: "T.", "F.", "N.". A jovem "T.", enteada de "F.", é descrita na narrativa como uma jovem problemática, maltratada pelo pai, "N.". Para consolá-la, "F." deixa em 
certo dia um hamster, animal de estimação da família, a cargo de "T.". Quando retorna a casa, porém, "F." descobre o animal morto: a menina "o apertou muito" e depois "o mandou contra a parede" (Costa 1994: 22). Acerca do cadáver do animal, chama a atenção o modo como a narradora descreve sua causa mortis: "Morto de mansuetude, estúpido" (ibidem; negrito meu). Ao presenciar a cena, a madrasta adverte a menina: "- Se fosse uma rata, Teresa, tinhas um corpo numa chaga, mesmo que fosse mansa" (ibidem; negrito meu). "T." torna-se assim a única personagem da narrativa a receber um nome completo: "Teresa". 0 ato de violência, portanto, conferiu-lhe uma identidade. Causar a morte de um ser foi a única forma de demarca-se contra a violência psicológica do pai, que lhe negava até mesmo o amor de uma madrasta atenciosa.

"Iniciais" constitui apenas um exemplo entre as diversas narrativas de Maria Velho da Costa em que a temática da violência surge em posição de destaque. Com efeito, não se trata de um exagero afirmar que é possível perceber, na obra da autora, um declarado fascínio pela violência em suas mais diversas formas, que marcam - e muitas vezes destroem - o destino de suas personagens.

No entanto, seria um equívoco acreditar que tal temática é representada pela autora apenas por um viés negativo. $\mathrm{O}$ fenômeno da violência assume frequentemente um estatuto ambíguo em seus textos: é comum que suas diversas personagens, vivendo em situações-limite, enxerguem na violência o recurso final para escaparem às condições que enfrentam, tal como ocorre acima com a jovem "T."/ "Teresa", sendo igualmente comum que tais ações desafiem nossos pressupostos acerca da moralidade. Em outras palavras, a temática da violência surge frequentemente em suas narrativas não apenas por representar atitudes facilmente classificadas como "violentas", mas antes como um dos objetos de reflexão da própria narrativa.

Nesse sentido, Irene ou o contrato social (2000) constitui um dos romances da autora que mais favorece o debate acerca da problemática da representação da violência em suas mais variadas manifestações, razão pela qual o elejo como objeto principal de análise deste ensaio. A obra narra a história da personagem Irene, acometida de Alzheimer, que a faz perder o controle não apenas de sua mente, mas também de seu corpo. Assim, em uma decisão sem dúvidas trágica, mas autoconsciente, Irene decide pôr fim a própria vida, gesto que entende como último recurso para sentir-se ainda agente de seu destino. Ela confia a execução de seu plano a Orlando, namorado de sua filha Raquel, e este pacto de morte torna-se um segredo que as duas personagens compartilham apenas entre si, escondendo a decisão de seus entes queridos. Assim, a violência surge no romance como motor de seu próprio enredo, o que nos permite abordar tal temática a partir de diversas perspectivas, que englobam, entre outras, não apenas o conceito de violência física, mas também o de violência psicológica, de violência estrutural e mesmo da violência enquanto forma de expressão artística.

\section{I.}

Irene ou o contrato social é um romance marcado por tríades, que longe de serem sagradas, são constituídas por conflitos: uma tríade de narradores (Irene, Raquel, Orlando), uma tríade de amantes (Raquel, Orlando, Cristóvão), uma tríade de assassinos (Leandra, Emílio, Orlando). 
Porém, muito da matéria narrativa do romance decorre como resultado do conflito envolvendo uma tríade em particular, formada por três personagens que habitam a mesmo casa: Irene, sua filha Raquel e a empregada Leandra, que muitas vezes é também referida pelo nome "Lia". Como tantos outros lares na obra de Maria Velho da Costa, a casa de Irene é palco de várias modalidades de violência, que se manifestam tanto por meios físicos como por meios mais sutis, operados pela linguagem, ao ponto de se tornarem imperceptíveis a algumas personagens.

Neste cenário, destaca-se a forte hostilidade que Leandra direciona a Raquel, cujo objetivo final parece ser a destruição das relações entre mãe e filha. Com efeito, é a própria Raquel que, ao rememorar os tempos em que esteve sob a constante ameaça de Leandra, afirma que "[e]ra ela, foi ela, que, despojada de tudo, fomentava a querela e os jogos de morte e do ciúme que me arredaram" (Costa 2000: 96). O primeiro capítulo de Raquel no romance já explora de forma bastante contundente a mágoa que a personagem carrega consigo, não apenas da empregada da casa, mas igualmente de Irene, que falha em perceber a exata dimensão daquilo que ocorre sob seu teto. Raquel, em seu exercício de escrita diarística, relata diversos exemplos que atestam como Leandra é habilidosa no manejo da violência da linguagem, usando desse recurso para envenenar a relação de Raquel e Irene. Como lembra Raquel, "era sempre" Leandra "que corrigia as pessoas quando diziam que eu me parecia com Irene, 'Não, a menina não é dela, foi trazida.' Foi deixada" (idem: 21). Diante de Irene, Leandra mantém "um tom de ameninamento, de mimoseira" (idem: 22), disfarçando a violência psicológica com que trata Raquel nos momentos em que as duas estão a sós.

Sendo vítima de tal hostilidade desde muito cedo, Raquel sente-se incapaz de confrontar Leandra. Mas o domínio que esta exerce sobre aquela não se perpetua apenas por meio da tortura psicológica. As ações de Leandra também atingem seu zênite de crueldade por meio da violência física. O exemplo maior disso ocorre durante a infância de Raquel, quando Leandra queima um gato vivo diante de seus olhos, sem que Irene jamais tome conhecimento do ocorrido:

Mal sabia ela que eu vira Leandra untar um pirex com óleo preto das fritadas e pôr lá um gato vivo que se foi encarquilhando sem abrir os olhos. Não gritei, não disse. Estava fascinada, tinha nove anos, Leandra puxava-me os cabelos, o que não deixava marcas, dizia que mentia. E mentia, e minto, com o gato cremado entalado na garganta. Leandra ria, eu estava fascinada. A vida é assim. Era assim. Depravada. (idem: 62; negritos meus)

Na passagem acima, destaca-se não apenas a frontalidade da descrição da violência, com o gato vivo "encarquilhando sem abrir os olhos", mas igualmente o prazer ("Leandra ria") com que a criada conduz o brutal gesto diante de uma Raquel ainda criança, a qual - já adulta no tempo diegético em que nos relata o ato - não esconde ter ficado "fascinada" com a demonstração da crueldade da qual era testemunha. A ação de Leandra igualmente desvanece a distinção entre violência física e psicológica: embora Raquel seja fisicamente agredida 
("Leandra puxava-me os cabelos"), o domínio de Leandra torna-se completo por igualmente denegrir as palavras de sua vítima, acusando-a de mentir. Não há cicatrizes ou outras marcas no corpo de Raquel, contudo a imagem que contempla, bem como as ameaças que sofre, afetam-na em plano profundo. Leandra torna-se assim a primeira das três personagens homicidas do romance, adiantando-se a Orlando e a Emílio. E tal afirmação não deve causar estranheza: há, na passagem acima reproduzida, uma vida a ser cruelmente interrompida, ação motivada apenas pelo puro exercício do poder e da crueldade.

Mas não se pode esquecer que Raquel é também vítima da cena que presencia, ainda que não seja seu corpo aquele destruído pela ação de Leandra. Trata-se de uma cena ficcional que representa de modo extraordinário o poder destrutivo da dimensão psicológica da violência. No campo dos estudos filosóficos, o reconhecimento de uma dimensão psicológica da violência foi objeto de algum debate. Pensadores como Joseph Betz, por exemplo, argumentam que o conceito de violência deve compreender apenas as ações onde há o uso da força exercida contra alguém, com intenção de feri-lo fisicamente: "There is no psychological or covert violence, I would claim, except by analogy and extension, simply because all violence is necessarily and by conventional definition overt or physical" (Betz 1977: 342). Newton Garver, uma das mais influentes vozes deste debate, apresenta uma percepção oposta à de Betz, considerando premente a necessidade de reconhecermos que a violência também se exerce por meios psicológicos, aspecto que, afirma Garver, pode ser tão ou mais destrutivo que sua variante física. Nas palavras do filósofo:

If we fail to recognize that there is really a kind of psychological violence that can be perpetrated on people, a real violation of their autonomy, their dignity, their right to determine things for themselves, to be humans rather than dogs, then we fail to realize the full dimension of what it is to do violence to one another. (Garver 2013: 176)

O "riso" com que Leandra tortura Raquel é também indicador de um outro aspecto da violência que não pode ser aqui negligenciado. Esse prazer derivado da violência incorpora ao romance de Maria Velho da Costa uma outra temática: o conceito do mal. Trata-se um aspecto frequentemente associado às ações de Lia, enunciado mais frequentemente pela voz de Raquel, mas igualmente presente nas descrições fornecidas pelos diálogos de outras personagens: Cristóvão define Leandra como "um monstro iníquo" (idem: 105), enquanto Orlando a considera "má. Maldosa. Mesquinha" (idem: 187). Mesmo Irene, em sua doentia dependência de Leandra, descreve-a como "odiosa" (idem: 57) e define a relação das duas como um "comércio de peçonha" (idem: 18).

Há muito a fortuna crítica de Maria Velho da Costa identifica o mal como uma temática recorrente em sua obra. António Guerreiro, por exemplo, em um recente artigo vinculado ao jornal Público, afirma que

[s]e um dia se escrevesse um livro, à maneira de um Bataille, sobre a literatura portuguesa e o mal, 
Maria Velho da Costa teria direito a um suculento capítulo. Ela conhecia como ninguém os desígnios do mal e da crueldade e fez deles matéria preciosa dos seus livros. O mal foi, com muita frequência, a sua "matéria de Bretanha". E há nela, muitas vezes, uma deleitação imoral. (Guerreiro 2020: 32; negritos meus)

É significativo que Guerreiro tenha recorrido a Georges Bataille ao refletir sobre a representação do mal em Maria Velho da Costa. Afinal, o filósofo francês, no conjunto de ensaios que formam sua célebre obra A Literatura e o Mal, subordina frequentemente a temática do mal à expressão destrutiva da violência. Porém, muito da originalidade da abordagem de Bataille deriva da associação que o filósofo estabelece entre o exercício do mal e um certo princípio do prazer:

Não podemos considerar como expressivas do Mal aquelas acções cujo fim é um benefício, um proveito material. Esse benefício, sem dúvida, é egoísta, mas pouco importa se esperamos outra coisa além do próprio Mal, uma vantagem. Enquanto no sadismo se trata de fruir da destruição contemplada, sendo a destruição mais amarga a morte do ser humano. É o sadismo que é o mal; se matarmos por um benefício material, não se trata do verdadeiro Mal, do Mal puro, a não ser que o assassino, para além do benefício obtido, tenha sentido prazer no acto. (Bataille 2016: 13; negritos meus)

Em suma, Bataille compreende o mal como o prazer de exercer a violência. A forma do mal, do "Mal puro", é "mais perfeita" (idem: 12) quando encontra sua finalidade em si mesmo, no prazer que se extrai da destruição e, podemos acrescentar, do exercício do poder sobre os outros, implícito aos atos de crueldade, o que fundamenta a certeira formulação de António Guerreiro, ao sugerir que o mal em Velho da Costa é uma espécie de "deleitação imoral". Ora, mais do que uma simples sugestão, a interseção entre o exercício da maldade e o prazer surge textualmente marcada em Irene ou o contrato social, quando a personagem homônima, ao admitir seu completo desconhecimento acerca da natureza do mal, afirma, referindo-se a si mesma na terceira pessoa:

Mas Irene percebia mal, muito mal a meu ver, que não percebia a maldade. Chamava-lhe ganância, senilidade, indiferença. Chamava-lhe tudo excepto os nomes que tinha. Prazeres. (idem: 54; negritos meus)

E tal prazer parece estar de fato na raiz das ações de Leandra. Afinal, não há ganho material algum na violência com que exerce seu domínio sobre Raquel. Mesmo quando sumia com "pratas, loiças, roupas, que Irene só lembrava meses depois", o seu maior ganho derivava sempre do prazer de denegrir a imagem da jovem perante a matriarca da casa: "'Atão não se lembra que a Raquelinha levou?" (Costa 2000: 21). Em diversas passagens do romance, é perceptível o forte teor erótico com que a narrativa descreve as "lembranças das maldades de Lia" (ibidem), a qual, ao testemunhar os confrontos entre mãe e filha, "ouvia e desviava os 
dentes à mostra, de puro gozo" (idem: 40).

Ainda assim, deve o leitor de Maria Velho da Costa lembrar-se de que não é costume da autora oferecer respostas únicas a temáticas complexas, e um conceito abstrato e polêmico como o Mal evidentemente não surgiria em sua obra por um viés definitivo. Seus romances não buscam o consenso, mas antes a desconstrução de certezas e a provocação de novas hipóteses de leitura por parte do leitor.

Dessa forma, se é possível apontar diversas passagens em que se destaca o prazer de Leandra em exercer a violência, como até aqui procurei destacar, isso ainda pouco diz acerca da natureza do mal e da razão pela qual alguns indivíduos buscariam essa forma específica de satisfação. Nesse ponto, o que encontramos no romance de Maria Velho da Costa é uma miríade de respostas: Raquel, já em seu primeiro capítulo como narradora, afirma: "ainda hoje tendo a pensar como Irene que a bruteza, com a sua carga de suspeição e inveja é toda a maldade que há, é a madre da maldade" (idem: 22 ; negritos meus). ${ }^{1}$

O uso de expressões como "toda a maldade que há" e, principalmente, "a madre da maldade" sugerem a totalidade de uma resposta acerca da temática abordada. No entanto, no parágrafo seguinte, ao lembrar-se de que, apesar das maldades de Leandra, era Irene quem Raquel "odiava de morte nesse tempo" (ibidem), uma nova raiz é associada à ideia da origem da maldade: "O que significa que também o abandono, ou o que é percebido como desamor, seja fonte do mal" (ibidem). Inveja, bruteza, abandono e prazer são, assim, sugeridos como possíveis "fontes do mal", o que está longe de representar uma resposta única para a questão. E tais possibilidades serão ainda confrontadas com a entrada de Orlando na vida de Irene e Raquel.

Seja quais hipóteses estejamos dispostos a procurar ao refletir sobre a representação da violência e da crueldade em Maria Velho da Costa, penso que elas devem encontrar seu princípio e seu fim na esfera das relações humanas, não parecendo que, em suas narrativas, lhe sejam atribuídas quaisquer origens metafísicas, ainda que por vezes a violência surja associada ao mal.

Alain Badiou nos lembra que, no pensamento ocidental, o conceito do mal tem uma origem religiosa, o que carrega consigo um entendimento cultural difícil de se desvencilhar (Badiou 1995: 69). Dessa forma, alerta para o fato de que essa atribuição é pouco produtiva, pois pode gerar a ilusão do consenso, uma definição a priori que a investigação filosófica deve rejeitar. Essa preocupação era já compartilhada por Bataille, o qual entende que "a divina embriaguez" do mal deve ser pensada "distante de qualquer religião" (2013: 18), procurando compreendê-la a partir da compulsão destrutiva dos seres humanos.

Maria Velho da Costa, em entrevista concedida a António Cabrita e Francisco Belard, quando interrogada a respeito da representação do mal em sua obra, fornece-nos uma resposta que entendo como bastante próxima às reflexões sugeridas pelos dois filósofos: a percepção de que o Mal, se existe algo que possa ser assim classificado, não deve ter suas origens explicadas pelo discurso religioso, mas antes pela ótica da violência. Conforme afirma a própria autora: 
Eu acho que, ao contrário da Agustina [Bessa-Luís], não percebo nada do mal e, voltando à criança tonta que eu era, acho que é por isso: eu tenho tendência a denegar o mal e a ter uma postura não metafísica em relação ao mal, a achar que o mal é a dor e que todo mal tem origem no sofrimento. [...] Acho que é mais da ordem daquilo a que Lacan chama denegação; o mal é só dor, portanto se não houver dor nem sofrimento o mal não existe. Ora se o mal não existisse não existia Universo. Porque a partir do momento em que há Universo [...] necessariamente há dor. (apud Belard/Cabrita 2002: 4243; negritos meus)

Acima sugeri que o mal, conforme praticado por Leandra, é uma expressão da violência sádica. Isso não significa que toda expressão da dor e da violência em Maria Velho da Costa surja colorida pela ótica da maldade. Pelo contrário: a temática da violência, nas narrativas da autora, não se esgota no conceito do mal, mas engloba-o. Há, portanto, diversas representações da violência nas obras da autora onde não parece existir o tipo de julgamento moral naturalmente associado à problemática da maldade. Penso, por exemplo, no capítulo inicial de Missa in Albis, em que crianças enterram "um alfinete de ama" na "barriga da perna" de Ema, a esquizofrênica, que reage, sem maldade, atirando as crianças para longe, gesto que a narrativa descreve como uma forma de afastar "pequenos gatos que houvessem exagerado no jogo de apuro de unhas" (Costa 2015: 29-30). No mesmo romance, há também os jogos de dor e prazer de Simão e Sara, que mordiam as mãos um do outro até a dor os impedir de enxergar (idem: 39-40). Em Dores, temos o já citado caso da criança que mata seu hamster pela incapacidade de discernimento, reflexo da violência que vê em casa. Porém, conforme discutido no início deste artigo, essa mesma violência é responsável pela fundação da sua identidade. Em Corpo Verde (1978), em uma sensualidade violenta que mais uma vez ecoa Bataille, o prazer da experiência sexual é frequentemente indissociável de alguma medida de dor infligida nos corpos dos amantes: "Agarra o meu cabelo que eu te arredondo o mundo" (Costa 1979: 18). Nesses exemplos, não parece haver qualquer associação entre a violência e o mal. Em Irene ou o contrato social, ao contrário, a intersecção entre esses dois conceitos parece mais frequente. ${ }^{2}$

Na casa da personagem Irene, há um prazer secreto em causar e sentir dor, a si mesmo e aos outros. Irene Ramalho, em seu ensaio do romance Myra, classifica-o como "um romance de extrema clarividência sadomasoquista" (Ramalho 2013: 55). Tal afirmação pode também ser apontada como uma constante entre as personagens de Irene ou o contrato social: as próprias descrições metafóricas o acusam, como "a sevícia deliciosa do remorso" (Costa 2000: 40), utilizada para descrever o ciclo de conflito, culpa e arrependimento que marca as relações de Irene e Raquel, sempre à sombra da influência nefasta de Leandra.

II.

O leitor de Maria Velho da Costa está habituado ao fato de que o recurso ao intertexto é uma das marcas recorrentes de sua escrita. Assim, é evidente que um conflito entre uma "Lia" e uma "Raquel" remete-nos diretamente ao texto bíblico, mais especificamente aos capítulos 29 a 31 do livro de Génesis, que tratam do patriarca Jacó e suas duas esposas, Lia e Raquel, 
irmãs que disputavam o amor do marido. Maria Velho da Costa, como é costume em sua obra, explicita textualmente essa referência, mas por meio da citação a outro texto: o poema de Camões, relembrando ser Raquel "a filha por prémio pretendida". No entanto, a dimensão sagrada do episódio bíblico é profanada de diversas maneiras: seria equivocado afirmar que Raquel e Lia, personagens de Velho da Costa, disputam o amor de Irene. Leandra, ou Lia, não é uma filha primogênita que disputa um direito legítimo de sangue, mas um agente da violência sádica, interessada na perversão não apenas de sua "rival", mas também da matriarca da casa.

Raquel, então, enxerga na fuga a única maneira de isolar-se dos conflitos que a cercam. Mas os caminhos que traça para si não são isentos de violência: incapaz de enfrentar Leandra, e sem o desejo de verdadeiramente ferir Irene, Raquel volta então sua agressividade contra si mesma. E, como acima sublinhamos ser uma constante neste romance, tais formas de autopunição escondem em si uma declarada parcela de prazer.

O deleite oculto no exercício da dor surge, por exemplo, no modo como a personagem nos relata o tempo em que enfrentou crises de anorexia. Ocorridas ainda na época em que habitava a casa de Irene, tornaram-se mais uma forma de Leandra exercer seu poder, pois esta, ao invés de informar a dona da casa, apenas estimulava o comportamento da jovem:

Era ela [Lia] que comentava sem alarme as minhas idas à casa de banho a seguir a cada refeição como sendo desarranjos intestinais e me fazia caldos de arroz, pudins de gelatina vermelha com sêmola que eu descobri serem muito fáceis de vomitar e até agradável, com aqueles filamentos e grumos que a sanita engolia como se fossem coalho de mênstruo. (idem: 21; negritos meus)

A violência que Raquel direciona contra si passa também pelo debate acerca da tematização das drogas no romance. Manuel de Freitas já assinalara "a coragem e o assombramento" (Freitas 2002: 164) com que, por meio da voz de Raquel, Maria Velho da Costa faz "valer sobre a hipocrisia reinante e a caridade do extermínio o direito de cada um a reivindicar o seu inferno e paraíso" (idem: 165; itálicos do autor). Nas palavras da personagem:

O que eu amo na droga - que eu amo a droga, a luminosidade do pó branco, mais que o transporte do cavalo $^{3}$ - o que eu amo na droga é a indiferenciação aprazível de tudo - a asa nervurada de uma abelha não é menos bela que o teorema de Tales, ou um montículo de esterco menos que a apara da unha, nem precisa de ser de Semíramis. Passada, tudo rima com tudo. (idem: 64)

Mas a leitura que aqui proponho se distancia em alguns aspectos da formulada por Freitas, especialmente porque penso ser igualmente fundamental destacar, na própria economia narrativa do romance, a intercalação entre violência e prazer sugerida pela linguagem de Raquel ao descrever sua relação com as drogas. Ao mesmo tempo em que luta para abandonar o vício, a personagem, com efeito, não hesita em declarar a falta que sente das drogas, em passagens cuja honestidade revelam a maestria de Maria Velho da Costa em desnudar os lados mais obscuros de suas personagens: "Merda, os estupefacientes são artefactos huma- 
nos. Seculares. Multiculturais. Orais, anais, sexuais. Não me venham sodomizar a alma com a boca" (idem: 65).

No entanto, não parece que a narrativa descarte simplesmente o papel autodestruidor que envolve as ações da personagem. Afinal, é Raquel quem afirma: "Pobre Irene, que abortou de mim que me abortei. Nada me diz ninguém, nem me extasia. [...] Mas também não tenho meios para morrer mais devagar ignóbil ou mais rápido" (idem: 94).

Independente de como se escolha ler a trajetória de desenvolvimento da personagem, a linguagem presente no romance, ao tratar do universo das drogas, passa também pela ótica da violência. Aliás, não apenas nas passagens em que descreve sua utilização, mas o processo de abstinência é igualmente descrito pela figurativização da agressividade e do dano: "Pois acordei com a angústia física, a das ressacas, a hospitalar, as parestesias ondulatórias, os fernicoques, como dizia Leandra, Lá está ela com os fernicoques, que não me deixam nem ficar quieta nem mexer como dantes e já lá vão tantos meses" (idem: 24). É, afinal, a própria Raquel quem descreve seu processo de recuperação como uma "violência a que me obrigo e me obrigam", apenas para logo em seguida abertamente admitir que "não passa um dia que não queira injectar-me, dormir, encher-me de ansiolíticos mais que a conta" (idem: 39). Há, assim, um conflito entre a violência da vida, da qual fora tantas vezes vítima desde criança, e a fuga proporcionada pelas drogas.

É Cristóvão, namorado de Raquel, o principal incentivador do processo de recuperação da jovem. Recebe-a em seu apartamento quando ela resolve abandonar a casa da mãe, estimulando-a também a recuperar a confiança de sua companhia de teatro e retomar seus trabalhos como atriz. Contudo, não há saídas fáceis na obra de Maria Velho da Costa, e aquilo que surge inicialmente sob a aparência de uma solução possível frequentemente transforma-se em mais uma forma sutil de violência. Velho da Costa não se deixa limitar por dicotomias simplificadoras: se fez da temática do mal uma constante em sua obra, parte da profundidade com que a aborda é reflexo também de sua capacidade em enxergar o mal que há dentro do coração do bem.

A descrição da personagem Cristóvão confere-lhe constantemente aspectos positivos: "Cristóvão faz-se assim. Bom, brasileiro, enfermeiro de almas, prático" (idem: 106). É também o "guardião" (idem: 66) de Raquel. É para ele que a jovem endereça seus escritos, mesmo que os dois dividam a mesma casa: "Vou deixar de fazer que te escrevo" (ibidem). Ele assume também o papel de mediador do conflito entre Raquel e Irene, procurando a mãe de sua namorada às escondidas e atualizando-a acerca do processo de recuperação da filha: "ele que é o informador de Irene do meu estado" (idem: 96).

Porém, os cuidados de Cristóvão revelam-se também uma forma de dominação sobre Raquel. A respeito da relação dos dois, escreve ela em seu diário: "Administra-me, eis tudo. Embora haja dias felizes, bem sei. É que estou a confundir um diário com um manuscrito endereçado. A consentir ser administrada. A admitir ser mais vista e ouvida, ouvista, que viva. Bem sei" (idem: 66-67; itálicos da autora, negritos meus). Haveria um limite nos gestos de cuidado que, depois de transposto, cercearia a liberdade daqueles que amamos? Maria Velho da 
Costa, como foi recorrente em toda sua obra, não procura clarificar essa diferença, mas antes explorar as situações-limite em que cuidado e dominação se confundem. Raquel enxerga que Cristóvão transpôs tais limites, não importando as boas intenções por trás de suas atitudes: "Eu choro, mas estou muito melhor. Tanto pior para C., o meu desvelado zelador" (idem: 167).

Relembro aqui as reflexões do já mencionado Newton Garver, que postula o direito à autonomia como um dos aspectos fundamentais do ser humano, definindo-o como "the right to dispose or cope with the consequences of one's action" (Garver 2013: 173). O filósofo sugere que impedir alguém de enfrentar as consequências de suas próprias ações pode constituir por si uma forma silenciosa de violência: "if we say that the results of what a person does belong to him, we should have in mind [...] also the more or less natural and expectable consequences of a person's action" (ibidem).

A observação de Garver torna-se pertinente como ferramenta de leitura das atitudes de Cristóvão quando consideramos, novamente, a linguagem que Raquel utiliza para descrever a relação de ambos, impregnada por diversas metáforas de violência: "E viviam felizes como um eunuco com a sua fanada favorita. Fanada no sentido da mutilação ginecológica que se pratica em crioulo da Guiné, o fanado" (Costa 2000: 107). A casa de Cristóvão, portanto, torna-se o terceiro ciclo de violência que Raquel atravessa no romance. Gradativamente, o espaço seguro que construíra com o namorado, onde estava protegida da violência de Leandra e da cegueira de Irene, transforma-se em outra forma de ameaça. É, mais uma vez, a linguagem metafórica de Raquel que reflete a dimensão de sua insegurança no espaço onde vive: "Faz o que fizeres o predador espera-te. Para te rebaixar, para te exaltar, para te comer, ó suave carocha entalada às portas da morte, credo!" (idem: 108).

Por último, não devemos ignorar um outro alerta de Garver acerca das várias faces da violência: a de que suas formas latentes sempre podem transformar-se em formas diretas de agressão física. Afinal, ao descobrir o envolvimento de Raquel e Orlando, é Cristóvão, o mesmo Cristóvão anteriormente descrito como "bom" e "curador de almas", quem a agride física e verbalmente: "E ele agarrou-me pelo cabelo e deu-me um estaladão, coisa que nunca tinha feito: Nigger lover. Puta" (idem: 167; itálicos da autora).

Apesar da mágoa que carrega da mãe, a trajetória de Raquel no romance inicia-se com sua saída da casa de Irene e encerra-se quando, como uma filha pródiga, encontra o caminho de volta. O que sempre odiou na mãe foi sua passividade, ou mais exatamente, a arrogância de sua pretensa bondade. Nas palavras de Raquel: "Era tonta, Irene, e tão correcta. Era isso que eu não podia perdoar-lhe. Ela era correcta por tentativa e erro, até que fosse tarde demais. Ela refulgia de razão e eu não podia adoptá-la, não podia. De razão diurna e eu tinha sido deposta nas trevas" (idem: 64).

Proponho ler a passividade de Irene a partir da temática da violência. O romance de Maria Velho da Costa é extremamente revelador em sua reflexão acerca da responsabilidade daqueles que nada fazem perante a maldade e a violência. Em um dos passos do romance, podemos ler: "[...] o mal também pode ser isso. Deixar, sem saber deles, a crueldade, o mal, acontecerem" (idem: 55). 
Irene, "esta Irene" (idem: 123), define o "horror do desleixo" como "a matéria do meu ser" (idem: 56). Não são apenas as suas relações com Raquel e Leandra que são marcadas pela inércia, mas também suas relações amorosas: a solidão a faz conviver com António Aurélio, "enfadonho e fátuo" (idem: 17), amante que some e reaparece de sua vida ao longo de vários anos. Mais madura, ainda assim envolve-se com Mota, homem de "estupidez altamente qualificada - um doido graforreico" (idem: 83), como se lhe refere Raquel em seu costumeiro (e certeiro) sarcasmo. Mota termina seu relacionamento com Irene por meio de uma carta "tão pulha de injúrias enfeitadas" (idem: 86) que ofende até mesmo Leandra. Irene, repetindo seu feitio passivo, nada faz frente às ofensas que recebe; assim, cabe a Raquel redimir a mãe: ao avistá-lo na rua em um certo dia, atira-lhe trocados "ao peito da roupinha coçada de avaro", mandando-lhe "comprar bolos de arroz" (idem: 87).

Desprovida do binômio camoniano "manha e força",5 Irene torna-se uma vítima fácil para o comportamento compulsivo de Leandra. Mas esta adota contra aquela formas mais subtis de dominação. O dialogismo, em Maria Velho da Costa, frequentemente opera por meio da sobreposição de referências intertextuais e interculturais, e tal recurso também está presente em Irene ou o contrato social. Dessa forma, se o conflito entre Raquel e Lia evoca, como aqui já referenciado, o episódio bíblico, a relação entre Leandra e Irene pode ser melhor compreendida pela referência a uma outra personagem, mas de origem shakespeariana: o traiçoeiro Iago, da peça Otelo. A associação é textualmente marcada no romance e surge a partir da voz da própria Irene: "Ah, que Iago era Lia, e digo era porque vivendo ela aqui comigo morreu para a minha afeição" (idem: 30).

A comparação não é superficial e assume flagrante importância a nível de construção de enredo. Primeiramente, já aqui observei que uma das razões encontradas por Raquel para justificar "o ódio que não cansa" (idem: 27) de Lia é a inveja; trata-se da mesma motivação que impulsiona o ódio de Iago contra Otelo, na peça shakespeariana: "Que razões tinha ela contra Irene, contra mim? Sempre as mesmas com que me debato agora - a mais perigosa das invejas, a que se representa como compunção e desvelo" (idem: 21). Assim, longe de ser o patriarca Jacó, a Irene do romance de Velho da Costa está mais próxima do papel do próprio Otelo, considerando que, à semelhança deste, Irene não enxerga a maldade e o desejo de destruição daqueles que a manipulam, mostrando-se totalmente indefesa frente à violenta compulsão de Leandra, eco da referência shakespeariana. A linguagem lisonjeira de Lia anestesia as forças de Irene, tornando-a dependente: "D. Irene, deixe o martelo quieto por cima da minha cabeça. A senhora nem força tem para empunhar uma colher. Deixe que eu vou fazer-lhe um café. Ora mais esta" (idem: 58).

Contudo, a personagem de Maria Velho da Costa subverte o desfecho sofrido pelo seu antepassado intertextual: Otelo, afinal, falhou em perceber o mal do qual era vítima até ser tarde demais. Irene, ao contrário, escreve suas memórias; confronta-se, narrando a si mesma na terceira pessoa. Esse olhar de fora sobre si permite-lhe, aos poucos, reconhecer o quão fugaz é seu conhecimento acerca dos desígnios da violência: 
Irene era demasiado triste para perceber, sempre fora, a crueldade simples. Ia aos animais e às plantas. Mas isso não se encontra em natureza nenhuma - nem ela encontrou - a crueldade simples, a simples crueldade.

Porque era de um mau gosto obsceno. (idem: 54)

A epifania da personagem ganha corpo no oitavo capítulo do romance. Ao reconhecer o prazer escondido na violência, Irene pode compreender melhor a motivação de todos aqueles que "não temiam o desgoverno" (idem: 78), como era o caso de Leandra, e mesmo de Raquel. Ao confrontar-se com tal questão, Irene é obrigada a admitir sua ingenuidade, que resultou no afastamento de sua filha:

narcisa demais, [Irene] não percebia o prazer de causar dor pelo cu das coisas. O prazer de fazer o mal porque faz doer, o simples prazer da dor num pontapé num gato, queimar um pau numa carne, cegar um pássaro nos dois olhos com fósforo, porque sim. (idem: 54-55; negritos meus)

Georges Bataille, em A Literatura e o Mal, embora destaque que o hábito da perversidade pode "degradar" o comportamento humano, alerta também sobre a necessidade de o mal rebelar-se contra bem. O mal, reforça Bataille, também tem o seu quinhão no mundo:

O ser não está voltado ao Mal, mas deve, caso o possa fazer, não se deixar encarcerar nos limites da razão. Deve começar por aceitar seus limites, tem de reconhecer a necessidade do cálculo do interesse. Mas, face aos limites e à necessidade que reconhece, deve saber que nele uma parte irredutível, uma parte soberana lhe foge. (Bataille 2016: 27).

Mas não penso que há, em Maria Velho da Costa, alguma apologia da violência. A epifania de Irene sugere antes a necessidade de reconhecer a violência como um dado concreto da vida, ao qual sempre se está exposto. É necessário também possuir um grau de agressividade para defender-se contra ela. Em suma, é preciso não morrer de "mansuetude" (Costa 1994: 22), como o hamster do conto "Iniciais", que abre as reflexões deste ensaio. Raquel, sempre uma personagem mais clarividente que Irene, observa: "Já reparaste que nenhum serial killer morre de cancro? A forma nova é ele. Nenhum assassino morre de cancro. Não podes nada contra a morte se não matares primeiro" (Costa 2000: 66).

Aos poucos, Irene percebe e assimila essa lição, entendendo que não há vida que não se imponha sem alguma medida de agressividade:

Como amigdalite infantil onde tropece o percurso da história - uma amigdalite de berçário contra uma greve geral. A diarreia de um cão nosso contra o avanço de um esquadrão de tanques, até o último momento. A pessoa humana inerme, a pessoa canina inerme, um pobre rato inerme. A vida? Não. A insustentabilidade de todo o sofrimento como nosso sofrimento. Avança, avança, exército tremendo, a célula neoplástica tem direitos sobre a tua misericórdia? O ácaro sobre a alergia do teu filho? Tigre que 
brilhas, ardes fulgurosamente sobre o teu cordeiro de peito? Onde pára, Irene, o teu amor da morte que é vida e da vida que, num simples vidoeiro que ameaça a colheita, é a morte? (idem: 53)

E assume a própria culpa no afastamento de Raquel: "Foi assim que amando Raquel tanto quanto o seu coração parvo, empequenecido, o permitira, ela a deixou, sem a deixar" (idem: $55)$.

\section{III.}

É curioso que essa tensão violenta que corrói a casa de Irene seja rompida apenas com a inserção de um outro elemento, de dimensão ainda mais agressiva, na dinâmica das personagens. Refiro-me a Orlando, uma das mais complexas personagens de Maria Velho da Costa, cuja identidade fluida resiste a classificações redutoras: nas marcas que traz no corpo e em suas atitudes, encontram-se pulverizados os limites da razão e da emoção, da passividade e da agressividade, do colonizador e do colonizado, bem como outras divisões, como os conceitos de nacional e estrangeiro, ou mesmo as posições de centro e margem na esfera social. Orlando não apenas atravessa as fronteiras dos dualismos, como também se transpõe a outros romances de Maria Velho da Costa: é ele um dos protagonistas de Myra (2008), última obra da autora. Para os propósitos deste ensaio, será destacado aqui apenas seu papel em Irene ou o contrato social, embora algumas alusões ao romance posterior sejam evocadas a fim de melhor elucidar alguns dos aspectos aqui explorados.

A trama de Orlando desenvolve-se, por um longo espaço do romance, paralelamente àquela protagonizada por Irene e Raquel. Ele surge, já como um dos narradores, no $5^{\circ}$ capítulo e envolve-se efetivamente no enredo das duas outras personagens apenas no $19^{\circ} .6$

O momento mais dramático desta personagem na narrativa ocorre quando Orlando, rapaz de pele parda, mata um skinhead acunhado de Spider. Nesse confronto entre um imigrante de origens africanas e um supremacista branco, há também forte alegoria, novamente explicada pelo diálogo com Shakespeare, dessa vez com sua derradeira peça teatral: A Tempestade. Esse paralelo exige alguma contextualização, a fim de que possa ser melhor compreendido.

É por meio dos capítulos narrados por Raquel que surge mais claramente o intertexto entre este romance português e a peça teatral inglesa. A filha de Irene, ao retomar sua carreira como atriz, está a ensaiar para o papel de Miranda, personagem com quem pouco se identifica, por considerá-la uma "menina sonsa" (idem: 65) e "tapada" (idem: 129). Esforçando-se para melhor compreender a personagem shakespeariana que terá de interpretar em palco, Raquel passa então a comparar as demais personagens do romance de Velho da Costa com as criações do escritor inglês. É nesse jogo lúdico de paralelos que formula então sua primeira impressão de Orlando, ao vê-lo à noite, após uma longa sessão de ensaios:

A alguns metros de distância, vinda da esquerda, aproximava-se uma estranha parelha: um jovem, alto, deslumbrante, todo vestido de linho branco, ou o que o parecia, com um enorme Rottweiler à trela curta numa coleira encadenada de três voltas. A passo, em calma. Fine apparition! My quaint Ariel... 
Cadernos de Literatura Comparada

Da dor e do secreto prazer: notas sobre a representação da violência em Maria Velho da Costa

Digamos que era mais um Caliban em metamorfose, pois a pele, as feições e o cabelo eram de mestiço claro. (Costa 2000: 134; negritos meus)

A comparação de Orlando com Ariel e Caliban representa um dos vários momentos em que o texto shakespeariano assume o papel de espelho temático do romance Irene.... Destaquemos aqui a formulação "Caliban em metamoforse", creditada por Raquel ao fato de o jovem rapaz possuir "a pele, as feições e o cabelo" de "mestiço claro". Tal passagem, bem como diversas outras que serão a seguir abordadas, inserem o romance de Maria Velho da Costa em um longo debate revisionista que interpreta a peça de despedida de Shakespeare a partir de uma ótica pós-colonialista.

Fátima Vieira afirma que diversos estudos surgidos na segunda metade do século XX sugerem uma leitura pós-colonialista de A Tempestade, em que Próspero assumiria o papel de "estandarte do imperialismo inglês que invadiu e usurpou a ilha do bom selvagem"; este último seria, portanto, representado por Caliban, convertido "no ícone cultural do índio americano, oprimido pela Europa sofisticada" (Vieira 2001: 19). Vieira observa que tal interpretação não é consensual no campo dos estudos shakespearianos, citando o exemplo de estudiosos como Leo Salingar, para quem "a mentalidade colonialista estava ainda em formação em Inglaterra em 1611" (apud Vieira: 21), sendo, portanto, pouco provável que tais correspondências pós-coloniais tenham sido detectadas na recepção da peça.

No campo das artes, a possibilidade de uma releitura pós-colonial da "peça de despedida" de Shakespeare serviu de mote para um número bastante vasto de poemas, romances e peças de teatro, frequentemente destacando - e reconfigurando - o conflito entre Próspero e Caliban. Rui Carvalho Homem, em um artigo dedicado a alguns exemplos de aftwritings desta peça shakespeariana, observa como Caliban foi reimaginado como um escravo negro por autores como Aimé Césaire (Homem 2012: 124), transformando-se, assim, em uma espécie de "torchbearer for a cause that coincides with the transatlantic narrative of uprootedness, slavery, engrafted cultures and languages" (idem: 125). Enquanto isso, ao longo do último século, a representação de Próspero não seria mais limitada ao simples papel de colonizador, mas potencializada como símbolo do poder em sentido lato, "by his reputation as colonial and patriarchal oppressor in postcolonial and feminist approaches to the play" (idem: 128).

Irene ou o contrato social pode igualmente ser lido como um exemplo destes diálogos pós-coloniais com A Tempestade. Nesse sentido, as representações de Próspero e Caliban acima mencionadas assumem um papel fundamental na compreensão da temática da violência nos segmentos narrativos dedicados a Orlando. A seguir, procuro esclarecer a importância deste paralelo.

Em A Tempestade, Caliban conspira para assassinar Próspero, gesto que a própria personagem classifica como vingança, por enxergar o duque europeu como invasor na ilha em que vive. Seu plano consiste em surpreender o mago enquanto este dorme, destruir seus livros e esmagar sua cabeça com uma pedra. Mas Próspero é avisado do perigo por Ariel, outro de seus escravos, pondo fim a empresa de Caliban, que reassume sua subalternidade. 
Orlando, mulato e imigrante, cujas origens familiares remontam a Cabo Verde e à África do Sul, ou seja, espaços colonizados por europeus, busca igualmente a vingança: sua amiga Luísa é assassinada por Spider, o que leva Orlando a procurá-lo na noite de Lisboa, com a declarada intenção de matá-lo. A leitura aqui proposta, de um confronto entre opressor e oprimido, encontra forte fundamentação quando descobrimos que Spider é um skinhead, uma subcultura urbana cujas vertentes mais radicais apresenta fortes ligações com um ideário neonazista, como a supremacia da raça branca e o discurso de ódio contra minorias, sendo inclusive responsável, em Portugal, pelo assassinato de imigrantes de origem africana.

Há diversas passagens do texto que nos permitem sugerir que Luísa foi vítima de um crime de ódio racial. Rolf, padrasto de Orlando, pergunta ao "rapaz pardo" logo após a morte da jovem:

- Essa fräulein, Luísa, é de cor?

- De cor somos todos, Vater, excepto os albinos e até esses têm olhos cor-de-rosa. (idem: 118; itálicos da autora)

Contribui também para essa leitura uma passagem onde é apontado que Spider, escondido após o crime, "extirpara" almas "por serem negras" (idem: 92).

Assim, a supremacia racial que está na raiz das crenças de uma personagem como Spider, que o levam a dizimar aqueles que considera inferiores, não está distante dos modelos de representação que foram atrelados ao arquétipo de Próspero. É possível, portanto, ler o conflito entre o mulato Orlando e o skinhead Spider como a reconstrução paródica da luta entre colonizador Próspero (representado por um supremacista branco) e o colonizado Caliban (aqui, um imigrante de origem africana). Contudo, ao contrário do desfecho da comédia shakespeariana, a personagem de Velho da Costa cumpre seu objetivo e mata seu adversário, por meios bastante bárbaros, vale ressaltar, posto que Orlando mata Spider a machadadas. ${ }^{7}$

É evidente que mais de 3 séculos separam a peça de Shakespeare do romance de Maria Velho da Costa, mas parece-me igualmente evidente que a obra da autora portuguesa desafia seus leitores a relembrarem que os séculos de colonização europeia foram igualmente marcados por crimes de violência fundamentados também em ideais de superioridade racial e cultural, cuja real extensão ainda encontra alguma resistência no pensamento europeu contemporâneo. Como muito bem já observou Maria Irene Ramalho:

A expansão europeia, sancionada pela suposta superioridade da cultura ocidental e ostentando o poder superior do Ocidente, resultou na subjugação e exploração de povos, terras e animais em todos os continentes. A invasão e a pilhagem de África e seus povos e animais, a middle passage, o tráfico de escravos e o genocídio de tantos povos indígenas no chamado Novo Mundo são crimes que ultrapassam largamente qualquer outra atrocidade perpetrada pelos seres humanos ao longo da história. Não houve jamais mission civilisatrice, ou mesmo gesto "civilizador" ou domesticador, que não tivesse envolvido 
violência, destruição e morte. (Ramalho 2013: 55; itálicos da autora)

Há uma outra questão premente na motivação de Orlando que não deve ser negligenciada: seu já mencionado padrasto, Rolf, é um alemão sobrevivente do Holocausto ("suserano salvado dos fogos", idem: 120), ${ }^{8}$ bem como sua preceptora, Hannah. Esta, inclusivamente, é quem respalda a decisão de Orlando em assassinar o skinhead: "Mas Hannah sorriu e disse em yiddish, Exactamente, mein Kind, com toda a autoridade da tatuagem de números no braço que acabara de lavar de sangue" (idem: 92; negritos meus). É também sua voz que Orlando escuta enquanto executa seu crime:

Triff noch einmal, diz-me Hannah. Não acabou. Dá-lhe outra. Mata-o. Orlando cumpre o desejo de seu corpo, desfere de novo a machada da garagem com as mãos ambas, pelas costas, na escuridão da azinhaga onde ele se alivia, ouve o estalar daquela matéria, dura matter, que o seguiu por todos os despertares da Europa unida, acorda enfim, sem suor, frio ou quente. (idem: 116; negritos meus)

Spider e Orlando, assim, completam, ao lado de Leandra, a tríade de assassinos do romance. Mas há motivações bastante distintas no uso que cada um faz da violência: já aqui observamos como a violência psicológica que Leandra sistematicamente direciona contra Raquel é percebida pelas demais personagens como atos do que Bataille afirma ser "o Mal puro", a violência sádica, que se compraz do prazer em destruir. Spider, por sua vez, é motivado pelo puro ódio de seu ideário neonazista, ancorado na supremacia da raça branca e em um forte sentimento de xenofobia. Assim, como a desafiar quaisquer julgamentos fáceis por parte do leitor, a ação violenta de Orlando não surge no romance como consequência de um desejo perverso, mas antes como a reparação de um mal.

Ora, os diálogos das demais personagens que compõem a família de Orlando parecem corroborar tal leitura. Além de Hannah, Rolf também não parece condenar as ações do enteado: "Não foste o primeiro a matar nem serás o último. Foi um trabalho limpo. Sem testemunhas, com luvas, com álibi seguro. Ficas umas semanas, partes um ano. Richtig?" (idem: 118). Anastásia, mãe de Orlando, quase parece orgulhar-se da atitude do filho, quando este retorna do período que ficara escondido no exterior:

Mudou de tom e meteu-lhe a cara nas mãos:

- Deus, meu Deus da misericórdia, bu 'sta bunitu sima Shiva, o deus azul da frauta. Depois de matar, depois de andarilho mundo vasto. So handsome.

- Na Europa, ${ }^{9}$ nha mãe, não exagera. (idem: 143; itálicos da autora)

No entanto, não devemos nos esquecer de que Orlando é um "Caliban em metamorfose", conforme a descrição de Raquel, já aqui reproduzida. A leitura integral deste romance de Velho da Costa revela o mulato como a mais culta e articulada personagem da narrativa. Além disso, é a sua posição como enteado de um embaixador alemão que lhe permite utilizar a influência 
política da família, bem como seu vasto poder financeiro, para não só abafar o crime cometido como também esconder-se por um ano no exterior. Dessa forma, por possuir o poder monetário e o poder sobre a palavra, por usar sem reservas do seu adquirido privilégio social, Orlando também assume o papel de Próspero. Vive, portanto, entre Próspero e Caliban. ${ }^{10}$

Esse paradoxo em seu estatuto social não escapa às reflexões que acompanham a personagem. Ora, a estrutura familiar de Orlando é formada por uma imigrante cabo-verdiana (sua mãe), dois judeus alemães sobreviventes do Holocausto (Rolf e Hannah), e uma jovem mulata (sua irmã). Uma composição, portanto, que muito dificilmente associaríamos a alguma interpretação do arquétipo literário de Próspero, o "estandarte do imperialismo inglês que invadiu e usurpou a ilha do bom selvagem" (Vieira 2001: 19). O que poderia, então, fundamentar tal interpretação, a qual, como procuro demonstrar a seguir, reflete a posição do próprio Orlando frente a seus familiares nos últimos capítulos do romance?

A resposta a essa indagação envolve o enorme poder financeiro de sua família. Após o homicídio que cometera com as próprias mãos, após o ano em que vivera escondido pelo interior da Europa, "solto na escória de um continente" (Costa 2000: 112), Orlando parece adquirir uma consciência mais profunda de seu privilégio social, assim como o papel desempenhado pelo poder financeiro enquanto causador de forte violência estrutural. ${ }^{11}$ Embora essa mesma riqueza permita-o classificar sua errância pelo território europeu como apenas "uma travessura pesada" (ibidem), duvidando de que se trate "sequer de expiação" (ibidem), parece bastante evidente que o rapaz pardo volta a Portugal mudado, direcionando um severo olhar aos seus entes mais próximos. Isso fica evidente, por exemplo, já em sua primeira noite de volta, durante o jantar em família, um banquete sugestivamente denominado como "uma celebração próspera ${ }^{12}$ do pródigo" (idem: 146 )

Que sei eu desta gente, de facto? Um padrasto diplomata impoluto (mas não se ganha uma fortuna assim na carreira); uma mãe bela, valorosa e brava, como se diz de uma puta romana de alto coturno (mas não se sobe assim dos fundos da emigração crioula sem outra carreira); uma ama sem leite, sem crias, que escolhe sem hesitação a vingança, que escolhe a doença, ávida da destruição lenta, depois de ter resistido a tudo, a quase tudo; uma irmã vivaz, podre também de mimo e já ferida da injúria e do ciúme [...]. (idem: 146-147; itálicos da autora)

As reflexões de Orlando acerca dessa matéria alcançam seu cume quando passa a comparar o poder financeiro à violência de regimes totalitários, não hesitando em incluir nesses paralelos até mesmo os regimes nazifascistas. Em outras palavras, a exclusão e a repressão resultantes do poder monetário, na visão de Orlando, não se diferenciam assim tanto de regimes segregacionistas e ditatoriais. Compreender por que a personagem estabelece tal raciocínio obriga-nos a recuar, novamente, à vítima de Orlando: o skinhead Spider.

No ano em que vivera escondido no interior da Europa, Orlando é assombrado pelo homicídio que cometera. Trabalha com "as baixas tarefas de onde podia desaparecer sem rasto" (idem: 112) e confunde os sons ao seu redor com aqueles produzidos pela destruição do cor- 
po de sua vítima: "o crânio estala como as bolas de ténis pulsam na rede, som seco e baço" (idem: 116). Isso não significa, contudo, que tenha se arrependido de sua ação violenta. Ao lembrar de seu crime, reforça que, em sua perspectiva, tratava-se de "um crânio sem nada dentro senão matéria quase inerte, cor de burro quando foge. Matéria circunvoluta, estriada, como o deserto de Houston que ele também vira da janela da Executiva. Skinhead, cabeça de pele e osso e nada mais" (idem: 115; itálicos da autora).

Porém, agora que conhece o "baixo profundo" (idem: 114) do continente europeu, Orlando entende melhor não só sua posição na longa cadeia de desigualdades criadas pelo sistema capitalista, mas torna-se igualmente mais propenso a entender o lugar ocupado por sua vítima. É, afinal, apenas nesse período que o homem de quem roubou a vida recebe, enfim, um nome próprio na narrativa: "Spider chamava-se Emílio Amâncio da Silva" e "desenhava muito bem a fat" (idem: 115). Mas reforça igualmente o estatuto de criminoso reincidente de seu adversário, ao lembrar em seguida que este "não acabara o ciclo recluso em Tires" (idem: 115-116). Conforme anuncia a voz da própria personagem, não há aqui alguma espécie de "remorso", mas, antes, "o princípio" de alguma "compaixão" (idem: 115).

Orlando - mulato e imigrante, como já aqui reforçamos, mas também rico e membro de uma influente família - "matara um desgraçado que nem sabia o que era talher, nem sobremesa, quanto mais soufflé de espargos e cabrito de leite assado no forno com batatas novas" (idem: 145). E tal consciência, ainda que não seja um arrependimento, transforma-se no interior da personagem em uma espécie de repulsa ao privilégio de que sempre desfrutara.

Há diversas passagens do romance que relacionam as classes sociais mais abastadas à violência. Um jogo linguístico com a sigla inglesa wasps (White Anglo Saxon Protestants) sugere-nos o modo como a personagem constrói tal relação:

A opinião faz-se com as vespas. Wasps. Vespas. White Anglo Saxon Protestant. São loiras e pérfidas: um arremedo de abelhas. Abelhas amargas. Sabes onde põem os ovos?, no cu das joaninhas que explodem por dentro com as larvas delas. Elas são assim: vespas. Um fac-simile pavoroso de quem muita boa gente é mais fóbica que de cobras vivas [...]. (idem: 144; itálicos da autora)

A luta de classes - representada na passagem acima pelas vespas que não hesitam em destruir as joaninhas para se perpetuarem - ocorre não apenas no interior de uma população, mas em escala global. O ódio preferencial de Orlando nesse sentido são os Estados Unidos da América. Quando indagado por Rolf se não desejaria continuar seus estudos naquele país, o rapaz responde:

ORLANDO - Nielmals. Never. Nunca. I hate them.

- Alle? Todos? A comunidade hebraica, os italianos, os latino-americanos, os negros, detesta todos? Os polacos, os russos brancos, os índios?

Ordem decrescente.

- Todos, disse eu, todos têm o passaporte da morte. Vespas, sabe? Vespas. (idem: 148) 
Não resisto em observar como Maria Velho da Costa parece ressignificar o refrão "Unidos como os dedos das mãos", da famosa canção "Jornada", de Fernando Lopes Graça, conferindo-lhe um viés pessimista. Costumeiramente lembrado como um hino da luta pela democracia em Portugal, esse verso surge no romance por meio de um jogo linguístico com o nome do país norte-americano ("Estados Unidos"). ${ }^{13}$ Talvez seja possível ler nesta sugestão uma forte descrença de Orlando quanto à possibilidade de lutar contra uma elite do qual ele próprio faz parte: hoje, são as vespas que permanecem unidas como os dedos das mãos, a esconder os próprios crimes, tal como o faz a própria família de Orlando, a quem ele inclusivamente estende a comparação: "Schnell, schnell, mach schnell, alle zusamen. Todos juntos, como os dedos da mão" (idem: 146; itálicos da autora). Associada a tal contexto, a imagem parece adquirir uma conotação mais repressora do que libertadora. Corromper um significado histórico de um verso seria um alerta do poder de corrupção da linguagem? Afinal, é o próprio narrador-personagem quem afirma: "Na minha família é o crime que molda o carácter. E a competência das línguas" (idem: 147).

Manuel Gusmão já adiantara a ambiguidade fonética no nome da mãe de Orlando, Anastácia, conhecida no seio da família pelo diminutivo "Nasi", que "difere por uma letra e um acento de «nazi»" (Gusmão 2011: 266). Penso que há igualmente outras passagens no romance que respaldam a sugestão de Gusmão. Exemplo disso é a estranha escolha de palavras de Orlando quando pede desculpas a Raquel: "Dá-me tu a solução final" (Costa 2000: 180). Não podem a combinação de tais vocabulários, associados de forma tão explícita ao imaginário fascista, ajudar-nos a entender o tamanho da repulsa de Orlando ao perceber a possibilidade das origens criminosas da riqueza de sua família?

Contudo, como adverte o próprio Orlando, este romance "não é um conto de Natal, ressurreição e Páscoa, não é Bergman" (idem: 147). O ato de matar também o faz conhecer o prazer da crueldade, e nisso aproxima-se de Leandra, ainda que, diferentemente desta, ele compreenda de forma mais abrangente a extensão das consequências advindas de suas ações. Não esconde de Irene, quando enfim a conhece e a salva de um assalto, que sentiu "gozo" ao testemunhar o assaltante "fugir com o coração entre as pernas e a roupa de meses estraçalhada por um cão de luxo" (idem: 190). E se a mãe de Raquel entende que é uma reação natural humana, Orlando lembra-lhe que o prazer da crueldade "é tão humano como a sua acólita, açafata, como lhe quiser chamar, humilhá-la a si, perverter Raquel e afastá-las. Pode-se pensar numa cadeia de vexames, numa cadeia de infâmias, é tudo muito humano" (idem: 190-191).

Qualquer narrativa que trabalhe com a temática da violência naturalmente suscita um debate sobre ética e representação. Pode-se mesmo indagar: a consciência de Orlando redime-o de seu crime? É eticamente aceitável recorrer a violência para pôr fim a violência de outro? Compartilho neste sentido da opinião de Maria Irene Ramalho, que, em seu supracitado artigo, observa que não parece haver, no romance de Maria Velho da Costa, uma linha a demarcar de forma absoluta estes dois espectros de moralidade. Contudo, seus leitores são convidados a refletirem sobre o tema, inserindo-se assim numa longa tradição de debates acerca da ética inerente à representação da violência e à própria violência da representação. Uma perspectiva 
que entendo como bastante valiosa para a leitura das personagens deste romance é a proposta por António Sousa Ribeiro:

O problema, simultaneamente ético e estético, de como fazer justiça ao sofrimento real no espaço da representação mantém-se mais vivo do que nunca e continua a ter de ser equacionado hoje em dia [...] - apenas com a diferença, significativa, de que o horizonte das opções estéticas contemporâneas se ampliou de modo virtualmente inesgotável nomeadamente em consequência do gigantesco desenvolvimento e diversificação dos novos media. Mas ontem como hoje, o problema de saber se a representação da violência e a violência da representação contribuem para perpetuar o fechamento do ser humano na estreiteza da pulsão da morte ou, pelo contrário, representam uma lógica de desassossego susceptível de abrir espaços de significação e de interpelação renovados é uma questão que não consente uma resposta genérica e só pode ser decidida no plano da especificidade de cada resposta concreta. (Ribeiro 2013: 26-27)

Podemos encontrar um eco simbólica dessa visão em Orlando, que, como graffer, espalha marcas de violência e destruição pelas paredes da cidade, mas extrai desse vandalismo elementos de rara beleza e espanto, como a Capela Sistina que desenha nas paredes do CCB:

Do lado direito, a quase toda a extensão e de uma altura descomunal estava um mural pintado a spray de tons secos, sépias, negro, cinzas, magenta, ocre. $O$ traço e a mancha eram exímios e podia perfeitamente distinguir-se a estrutura distorcida da criação da Capela Sixtina (sic). Irene pensou, 'A alucinação aproxima-se de mim como eu me despeço de tudo. O medo vai ter tudo'. Porque aquilo era um feito tão medonho e belo como desmesurado. (Costa 2000: 79; negritos meus)

A descrição acima parte de Irene, que, ao observar o que efetivamente era a cena de um crime, "Tremia de curiosidade, tremia de choque" (idem: 80). Seria por isso que Irene se afeiçoaria tanto a Orlando, quando este começa seu envolvimento amoroso com Raquel? Afinal, a agressividade destrutiva de Orlando parece funcionar no romance como um complemento à passividade - também destrutiva - de Irene.

De qualquer forma, é Orlando o responsável pela reaproximação entre Irene e Raquel. Esta, agora amando e amada, encontra nisso forças para se reconciliar com a mãe, e a reaproximação das duas, tal como o despertar do amor entre os dois jovens, surge na narrativa fortemente carregada de signos da violência:

E Raquel veio. Para apanhar na cara e lembrar que o amor dói. $\mathrm{O}$ amor dói, mesmo feliz. Croce e delizia. Mais alto. Os vizinhos que oiçam e protestem; ninguém ama assim na minha rua. We are the dead dreams. Quero ir para casa. Irene entende-me e enxuga-me do choro e da alegria. Raquel já não anda extraviada. Essere amata amando. (idem: 171; itálicos da autora)

Há dor e sacrifício - portanto, violência - também na reconciliação. 
Um desafio ainda maior ao leitor surge já no final do romance, como a contrariar qualquer classificação definitiva: a violência é novamente evocada como a única forma de libertar Irene de seu sofrimento pessoal. O Alzheimer da personagem, violência do corpo contra o próprio corpo, da mente contra a própria mente, obriga-a a um pacto de morte com Orlando, pois precisa sentir que está a morrer com dignidade, ainda dona de si. É ela quem pede a Orlando que a execute.

Isso impõe ao leitor uma conclusão difícil, resistente a análises e definições absolutas, como se espera, aliás, de um romance de Maria Velho da Costa. Afinal, como interpretar um romance que trata de uma personagem que quase destrói a vida dos seus entes queridos devido a sua passividade, apenas para morrer, voluntariamente e em defesa de sua dignidade, nas mãos de um jovem assassino?

Uma passagem, já próxima ao fim do romance, parece-me às vezes negligenciada quando se trata de Orlando. O rapaz pardo indaga-se: "por que havia Irene de dar-me o desassossego de um crime mais, de uma morte que já estava certa?" (idem: 218). O trecho sugere-nos que Orlando termina a narrativa vendo a si mesmo como carrasco e vítima de seus crimes. Erich Fromm, em The Anatomy of Human Destructiveness, afirma que a violência pode destruir não apenas suas vítimas, mas "the destroyer himself" (Fromm 1990: 9). Destruição e crueldade "constitute a paradox: they express life turning against itself in the striving to make sense of it" (ibidem). Os dois homicídios executados por Orlando afetam-no significativamente, e a personagem surge modificada no romance seguinte: Myra (2008). Assim, uma análise integral da personagem deverá contrastar suas caracterizações nesses dois romances, aspecto que pretendo explorar em futuras publicações.

Isso não me impede, contudo, de formular uma conclusão para as problemáticas levantadas no presente ensaio: se há, nos romances de Maria Velho da Costa, um declarado fascínio pela violência, entendida como necessária para o desenvolvimento da vida, a representação deste tema em suas obras não exclui também seu carácter destrutivo. Compreender o estatuto ambíguo da violência, a autora parece sugerir, é fundamental para a manutenção de nosso próprio contrato social. 


\section{Cadernos de Literatura Comparada}

Da dor e do secreto prazer: notas sobre a representação da violência em Maria Velho da Costa

\section{NOTAS}

* Daniel Floquet graduou-se em Letras-Literatura pela Universidade Federal do Ceará em 2007, seguindo para a Faculdade de Letras da Universidade do Porto (FLUP) em 2008, onde concluiu o mestrado em Estudos Literários, Culturais e Interartes com a dissertação A Pulverização das Dicotomias em Myra, de Maria Velho da Costa. Atualmente, prepara a tese de doutoramento $O$ Sangue Puxa o Sangue: Representações da Violência em Maria Velho da Costa e Edna O'Brien, também na FLUP, com o apoio de uma bolsa de doutoramento da Fundação para a Ciência e Tecnologia (SFRH/BD/129705/2017). É investigador não-doutorado integrado do Instituto de Literatura Comparada Margarida Losa (ILCML) e colaborador do CETAPS, unidades de investigação ligadas à Faculdade de Letras da Universidade do Porto.

${ }^{1} \mathrm{O}$ comentário vem no seguimento da afirmação de que Leandra "era astuta e corruptora, mas bronca" (idem: 22).

${ }^{2} \mathrm{O}$ mesmo pode ser dito de Myra (2008), último romance da autora.

30 "cavalo" aqui mencionado é uma gíria para se referir a "heroína".

${ }^{4} \mathrm{O}$ uso do verbo fazer na passagem é também revelador da sutileza com que Velho da Costa constrói suas personagens. Cristóvão "faz-se" bom. O quanto há de performance em tal atitude?

${ }^{5}$ Binômio camoniano que seria uma das marcas da protagonista do romance seguinte de Maria Velho da Costa: Myra (Costa 2008).

${ }^{6}$ Há, no entanto, um breve encontro entre Irene e Orlando no capítulo 17.

${ }^{7}$ É possível ler aqui um comentário político na escolha da arma utilizada por Orlando: o líder do movimento skinhead português durante a década de 1990 chamava-se Mário Machado, acusado e condenado como um dos responsáveis pelo assassinato do imigrante cabo-verdiano Alcindo Monteiro, caso que recebeu considerável atenção midiática na ocasião. Assim, não deixa de haver uma certa ironia na ideia de que, no romance de Maria Velho da Costa, temos um imigrante cabo-verdiano a matar um skinhead a "machadadas".

${ }^{8} \mathrm{~A}$ informação é reforçada em Myra, na curta participação de Rolf no romance, em que é lembrado pelo seu destino "de criança escapa" (Costa 2008: 143)

${ }^{9}$ Ainda permanece por realizar um estudo sistematizado da influência pós-colonial na obra de Maria Velho da Costa, especialmente acerca do imaginário da África no conjunto de sua obra. Embora presente desde Maina Mendes, seu primeiro romance, trata-se de um elemento que adquire maior envergadura após a estadia da autora em Cabo Verde. "A Europa não é o mundo", lembra-nos a personagem Orlando, lembra-nos Maria Velho da Costa.

${ }^{10}$ Minha referência aqui, naturalmente, é o belo título de um dos mais famosos ensaios de Boaventura de Sousa Santos.

${ }^{11}$ Utilizo aqui o conceito de Violência Estrutural a partir da formulação de seu criador, Johan Galtung, que a define como a violência inerente ao sistema, resultado da desigualdade de acesso a recursos e oportunidades: "There may not be any person who directly harms another person in the structure. The violence is built into the structure and shows up as unequal power and consequently as unequal life chances" (Garver 1969: 171; negritos meus).

${ }^{12}$ O jogo de palavras entre "Próspero", nome da personagem shakespeariana, e "próspero", adjetivo em português, ocorre não apenas nesta passagem, mas em diversas outras do romance. Raquel, nos ensaios de A Tempestade, escreve: "Mirar Miranda. Tal pai, tal filha. Prósperos, admiráveis" (Costa 2000: 65).

${ }^{13}$ Tal associação parece possível por surgir na sequência de um noticiário com "imagens de Washington" (ibidem), que irritam profundamente Orlando. 


\section{Bibliografia}

Badiou, Alain (1995), Ética: um ensaio sobre a consciência do Mal, tradução de Antônio Trânsito e Ari Roitman, Rio de Janeiro, Relume Dumará. [1993]

Bataille, Georges (2016), A Literatura e o Mal, tradução de Manuel de Freitas, Lisboa, Letra Livre. [1957]

Belard, Francisco/Cabrita, António (2002), "Entrevista - Maria Velho da Costa", Expresso no 1552, 27 de junho, pp. 36-43.

Costa, Maria Velho da (1979), Corpo Verde, Lisboa, Contexto.

-- (1994), Dores, Lisboa, Dom Quixote.

- - (2000), Irene ou o contrato social, Lisboa, Dom Quixote.

-- (2008), Myra, Lisboa, Assírio \& Alvim.

- - (2015), Missa in Albis, Lisboa, Assírio \& Alvim. [1988]

Freitas, Manuel de (2002), "Da citação como uma das belas artes: sobre Irene ou o contrato social de Maria Velho da Costa", in Colóquio/Letras, nº 161-162, pp. 157-169.

Fromm, Erich (1990), The Anatomy of Human Destructiveness, Nova Iorque, Holt, Rinehart and Winston. [1973]

Galtung, Johan (1969), "Violence, Peace, and Peace Research", in Journal of Peace Research, Vol. 6, No. 3, pp. 167-191.

Garver, Newton (2013), "What violence is", in Violence: A Philosophical Anthology (ed. Vittorio Bufacchi), Hampshire, Palgrave Macmillan, pp.170-182. [1972]

Guerreiro, António (2020), "Maria Velho da Costa: a palavra literária em estado de apoteose", Público, 25 de maio de 2020, pp. 31-32.

Gusmão, Manuel (2011), Uma Razão Dialógica, Lisboa, Avante.

Homem, Rui Carvalho (2012), "Prospero's Wake: Genre and Transit in the Afterlife of The Tempest", Shakespeare Jahrbuch, $\mathrm{n}^{0} 148$, pp. 113-133.

Nietzsche, Friedrich (2015), Além do Bem e do Mal: Prelúdio a uma filosofia do futuro, tradução de Paulo César Lima de Sousa, São Paulo, Companhia de Bolso. [15ª reimpressão]

Ramalho, Maria Irene (2013), "A Violência da Cultura: Sexo, Espécie e Colonialidade em Maria Velho da Costa", in Representações da Violência (org. António Sousa Ribeiro), Lisboa, Edições Almedina, pp. 51-63.

Ribeiro, António Sousa (2013), "A Representação da Violência e a Violência da Representação", in Representações da Violência (org. António Sousa Ribeiro), Lisboa, Edições Almedina, pp. 7-34.

Vieira, Fátima (2001), "Introdução", in A Tempestade, Porto, Campo das Letras. 